\title{
Analyzing "Kubah" and Efforts to Reconcile the 1965 Tragedy
}

\author{
Muh. Fatoni Rohman* \\ University of Brawijaya
}

\begin{tabular}{l} 
A R T I C L E \\
\hline Keyword: \\
Conflict \\
Reconciliation \\
Actors \\
Offenders \\
Victims
\end{tabular}

\section{INTRODUCTION}

Indonesia is a nation that is blessed by a diversity of cultures, ethnicities, and religion. On one hand, this diversity can be considered as wealth, but on the other hand, it may be considered a threat if not managed well. A series of horizontal conflicts among ethnicities, races, and religion - as threats to disunity - have filled the historical record of Indonesia. Often, these conflicts still leave behind lingering remnants that at any given time can flare up and bring actors into a new conflict that creates a cycle of violence that is hard to break. The effort to break this cycle of social conflict will require an enormous amount of energy, cost, and struggle. This effort to break the cycle is not an individual one, but it takes the effort of the entirety of all aspects of society.

For readers of literature, the normative paragraph above will raise a variety of questions regarding the link between literature and conflict as well as its resolution. "What is the contribution of literature in the effort to resolve conflicts?" and "Has the function of literature as a way to spread kindness been utilized to the maximum?" are examples of questions that address literature and conflict. These questions certainly refer to the understanding of literature as a tool to spread kindness, that is, literature as something dulce et utile. Literature is not simply belleslettres, a beautiful work (Teeuw, 1988: 51; Welleck and Warren, 1989: 25; Zoetmulder, 2011: 1052). In addition to regarding the involvement of works of literature, the relation of literature and conflict may also regard the involvement of writers as those that create the works.

Horatio (in Teeuw, 1988:51) mentions that the primary task of a writer is "docere et delectare" - to teach and to delight. This primary task is in relation to how artists give realization on the concept of living in society. Writers are a part of society and literature is the subjective viewpoint of writers toward the acts of society. Oftentimes, what is recorded in a work of literature is a real-world event that is processed according to the scope of the writer. Literature is an imaginary world that lives in the mind of the writer, but the creative idea as the seed of that imagination is the reality that exists in the real world. Social conflict is one of the realities that often occurs as the inspiration for the creation of literature.

The 1965 tragedy is one of many social conflicts that have occurred in Indonesia. Several authors have made the 1965 tragedy as the inspiration for their works, whether as an insert or as the primary setting. Umar Kayam inserted the 1965 event in his novel, Para Priyayi (1992), by presenting the character of Harimurti who became an activist of the communist artistic organization (Lekra), who was then arrested and detained, accused of being involved in the 1965 tragedy. Harimurti was able to be freed because of the interference of his uncle, who was a high officer in

\footnotetext{
${ }^{*}$ Corresponding author.

E-mail addresses: muh_fatoni@ub.ac.id (Muh. Fatoni Rohman)
}

2597-7385/ @ 2017 ISLLAC Journal. All rights reserved. This is an open access article under the CC BY license (http://creativecommons.org/licenses/BY/4.0/).

89| ISLLAC : Journal of Intensive Studies on Language, Literature, Art, and Culture 
the TNI (Indonesian Military). Harimurti in the novel Para Priyayi seemingly depicts of the "otherness" in the otherwise perfect Sastrodarsono family.

The story of Harimurti was followed up in the novel Jalan Menikung (1998) which told the story of the social effects and life struggles of former actors of the 1965 tragedy, who were considered "blots in the environment". Umar Kayam in these two novels placed "Harimurti" as the example of a person involved in the 1965 tragedy. Harimurti was considered the "guilty offender" who had to follow the will of the "winner".

In addition to the novels Para Priyayi and Jalan Menikung, Umar Kayam in the two novelettes of Sri Sumarah and Bawuk (1986) also revealed the story of the 1965 tragedy with all its consequences. Sri Sumarah told the story of the struggle of a mother who could only be sumarah (compliant) with the fate of her child who became involved in the 1965 tragedy. Meanwhile, the novelette Bawuk depicts the change in the fate of a daughter of the onder (administrative leader) of Karangandu in becoming an evacuee of the 1965 tragedy. Umar Kayam in these two novelettes gave a tragic ending to both of the main characters (Tun and Bawuk), by making both evacuees of communists who had to flee head over heels from communist officers and end up lost with their fates unknown. In line with the previous two novels - Para Priyayi and Jalan Menikung - in the two novelettes (Sri Sumarah and Bawuk) Umar Kayam also brought up secondary victims or actors with all the consequences that they had to bear.

Laksmi Pamuntjak made the 1965 tragedy as the primary setting in the novel Amba (2002). In this novel, the author told the story of a character named Amba who traveled to the island of Buru to look for her lover Bhisma - who was accused of being a communist party member - who was lost after the military invasion at the Res Publica university. This novel also portrayed the life struggle of Amba, who was unintentionally caught up in the 1965 tragedy and lost her lover, became removed from her family, and married an expatriate in order to seek safety. In the novel $A m b a$, the socio-cultural condition of the people of the island of Buru is also depicted, which became the place where political prisoners of the 1965 tragedy were exploited.

Laela S. Khudlori in the novel Pulang (2012) brought up the story of struggles of exiles and their descendants who lost their citizenships due to the 1965 tragedy and survived by opening up a Nusantara (Indonesian) restaurant in Paris, France. Laela S. Khudlori depicted clearly the fates of exiles - whose involvement in the 1965 tragedy is uncertain yet are considered as part of the event - in a foreign country. In it is also depicted how the exiles dearly miss their beloved homeland.

A similar situation was also written by Gitanyali in the two-book series Blues Merbabu and 1965, which told the story of the child of a communist party activist. Gita, the main character in the series, had to set aside the lineage and background of her family to be able to live in the Era Orde Baru (New Order era).

Ahmad Tohari was also an author who wrote novels with the setting of the 1965 tragedy in the Ronggeng Dukuh Paruk trilogy (published as a trilogy in 2003). The trilogy of Ronggeng Dukuh Paruk made the 1965 tragedy as the turning point of the life of Srintil of the famous dancer (ronggeng) of Dukuh Paruk who became a political prisoner of the 1965 and became insane due to the incredible pressure.

The novel Kubah by Ahmad Tohari is one of the few among novels themed after 1965 that attempted to present the 1965 tragedy in full, seen from the perspective of the lives of the conflict offenders. In addition to the entirety of perspective, another selling point of this novel is the audacity of the author to present a happy ending for a figure that is considered the primary perpetrator and actor (offender) of the 1965 tragedy. This selling point is very much meaningful for readers of literature, in particular as an effort to instill the discourse of reconciling the 1965 tragedy.

Before discussing the relationship of literature to conflict resolution, it would help to explain the theories behind the understanding and resolution of conflicts. Literally, the conflict has the meaning of a struggle that occurs because of a violation of rules or norms. Actors in a conflict always involve offenders and victims. Offenders are parties that violate norms and become the cause of the conflict, while victims are parties whose norms are violated in a conflict (Alif: 2015). For every conflict, problems must be solved (conflict resolution). If not, the new conflict will be created. The process of conflict resolution can be accomplished if an agreement is reached among parties in conflict by negotiating their positions, strengths, and resources. This agreement is useful to find a point of understanding so that clashes of interests no longer occur among actors in the conflict. This conflict resolution by way of reaching agreements occurs on a psychological level, at the point when all the parties have realized the necessity of a mechanism to end the conflict. In many cases, the achievement of conflict resolution has not been able to destroy the seeds of enmity among the parties in conflict.

One of the ways that conflict may be resolved is through social reconciliation. Reconciliation was the process of conflict resolution undertaken in South Africa after the liberation of Nelson Mandela in 1990. Reconciliation is an interpersonal happening that requires a commitment of both parties (victims and offenders) to terminate the conflict by forgiving and creating a harmonious relationship (Verdoleagee, 2008:1; Afif 2015:229-230). The objective of reconciliation is to repair social relationships and make peace among offenders and victims, instead of demanding retribution to the offenders (Jones 2006:377).

Kelman (in Alif, 2015: 236) explains that there are three primary processes that mark the success of a reconciliation. The three processes are (1) willingness, (2) identification, and (3) internalization. Todung Mulya Lubis, as published in Kompas (Nov. 20, 2014) states that there are three stages that must be followed by parties in conflict to achieve a reconciliation: (1) revealing the truth, (2) forgiveness, and (3) healing.

\section{DISCUSSION}

90 | ISLLAC : Journal of Intensive Studies on Language, Literature, Art, and Culture 
As mentioned above, the novel Kubah is one of the few novels themed after the 1965 tragedy that offers social reconciliation as conflict resolution. In-depth analysis of the contents of the novel Kubah can answer the question of how literature can contribute to resolving the conflict. The impression has always been that the attempt of relating literature with conflict resolution is neither here nor there. This could be because of the paucity of literature works that have the discourse of conflict resolution, or possibly because few studies have been published regarding literature works with the theme of conflict resolution.

In the case of the 1965 tragedy, it is indeed difficult to realize the practical function of literature as a medium for conflict resolution. As such, in this article, the discussion will be seen from two different points of view. The first viewpoint discusses the contribution of literature as a part of the global resolution of the 1965 tragedy, and the second viewpoint specifically discusses the value of reconciliation of the 1965 tragedy in the novel Kubah.

The 1965 tragedy is an event for which its truth today is still obscure. Each of the parties (actors in the conflict) still believe that they are on the right side. This truth is further affirmed by the construction of conflicting narratives of the event among parties involved in the 1965 tragedy (Notosusanto and Saleh (1989); SETNEG RI (1994); MABES ABRI (1994); Adam (2009); Crouch (1986); Sulistyo (2000)). When all actors in the conflict still hold onto the narratives that affirm their actions, social reconciliation will not occur. The longer this subjective truth is glorified and partiality based on the sameness of ideology is embedded, the greater the possibility of a society entering a neverending cycle of violence. The obscurity of this truth is accompanied by the unclearness of offenders of the 1965 tragedy. Each of the parties feels that they are a victim of the conflict, not the offender of the conflict. These tangled knots of truth may be taken advantage by certain parties who make the 1965 tragedy as a way to obtain personal gains.

One of the problems that make it hard to achieve reconciliation of the 1965 tragedy is the lack of credible information regarding the truth related to the event. This state of limited information allows literature to play a major role in creating a discourse of reconciliation for the 1965 tragedy. This role is very much possible considering the multitude of works written by author observations or even writings made by actors in the 1965 tragedy.

In addition to the several novels mentioned above, after the 1998 reformation, a variety of works that had the theme of the 1965 tragedy was published. These works are in the form of short story anthologies, novels, or personal narrative memoirs of conflict actors. The authors of these have different backgrounds and viewpoints in viewing the 1965 tragedy. This variety of viewpoints is actually beneficial for the reconciliation process because it is possible for all parties to find out the viewpoints of one another. When opposing parties position themselves not uniformly on one side, the agreement will occur, which becomes the foundation to increase willingness to accept the actions of other parties. This is in line with the opinion of Keelman (in Alif, 2015: 236) who states that the stage of willingness in reconciliation refers to the readiness of both parties to accept and recognize the expectations of the other to result in the desired response. This knowledge about the expectations of other parties will create new perceptions on the 1965 tragedy. When understanding occurs among actors, the process of reconciliation will also proceed to the stage of forgiveness. Forgiveness will occur if among the actors of the 1965 tragedy there is sympathy and empathy toward others. This sympathy and empathy will be created if the actors of the conflict are able to feel the burden that the other parties feel.

The primary target of literature as one of the media to reveal the truth of the 1965 tragedy, in addition to the conflict actors, is the new generation of readers of literature. These readers of literature are of the generation that was born after 1965. The post-1965 generation is a generation of readers of history, not a generation of actors of history. The more works that they read about the 1965 tragedy, without regard to who are offenders or victims, the greater is the possibility of an intermediate perception to be realized regarding the 1965 tragedy. This intermediate perception is not partial to or supportive of any one side but is instead the result of reading about the condition of both sides. The more works there are of the 1965 tragedy, the greater the opportunity becomes to reveal the truth of the 1965 tragedy. As such, this will create a generation that perceives the 1965 tragedy not from one side of actors, but from two sides of the actors involved in the conflict.

After discussing how literature possesses a role in the reconciliation effort for the 1965 tragedy, the discussion next concerns the reconciliation process proposed in the novel Kubah by Ahmad Tohari. As previously mentioned, the novel Kubah offers a form of reconciliation for actors in the 1965 tragedy. This value of reconciliation is what sets apart Kubah from other novels themed after the 1965 tragedy. Ahmad Tohari in Kubah provided a happy ending for offenders of the 1965 tragedy. A happy ending for the character of Karman in Kubah is an incredible thing.

Karman is no ordinary offender. Karman is the leader of a political party considered to be involved in the 1965 tragedy. In the real world, Karman is categorized as class A in the classification of political prisoners based on Inpres (Presidential Instruction) No. 13/Kogam/7/1966. The Inpres categorized the offenders or political prisoners of the 1965 tragedy into three categories: 1 ) class A, people who are actually directly involved, meaning those who aid or plan or know the existence of the rebellion but did not report to the authorities; 2) class B, people who are not actually directly involved, who are cadres that have sworn loyalty to the PKI (Communist Party of Indonesia), or administrators of public organizations affiliated to PKI and intentionally disrupt the effort to rid the PKI; and 3) class C, people who become members of public organizations affiliated to PKI, who sympathize or are influenced by PKI, or who were involved in the Madiun event (Setyawan, 2003:285-286). The Inpres also regulates the handling of offenders of the 1965 tragedy. People of class A were put on trial in courts of law. People of class B were exiled into one place, to avoid the ire of other people (to the islands of Buru and Plantungan). Lastly, people of class $C$ who were civil servants or employed by state enterprises were divided into three groups; group C1 was dishonorably discharged, while groups $\mathrm{C} 2$ and $\mathrm{C} 3$ faced other administrative, depending on the severity of the involvement. 
Based on the classification in the Inpres, the character of Karman in Kubah was an offender of class A or B because of the knowledge of and direct involvement in the 1965 tragedy. After the 1965 tragedy, there was a cleansing of those suspected to be involved in the event. Offenders of categories A and B in the real world have mostly been cleansed whether directly or indirectly (Kasenda, 2015: 85-87; Sulistyo, 2000:174-201; Tempo, October 2012). As reality presented the phenomenon of cleansing, the appearance of Karman who was accepted as a lost relative is an incredible thing. This return of Karman into society certainly has an interesting background to be analyzed, since it is possible that Kubah brings to the surface things that become the base for the reconciliation process after the 1965 tragedy. The cause of this reconciliation can appear in the self of Karman as an offender, or in Pegaten society as the victim of the 1965 tragedy.

Ahmad Tohari in the novel Kubah equally divided reconciliatory roles for and victims of the 1965 tragedy. The role of offenders in reconciliation, represented by the character of Karman, is to admit wrongdoing and apologize. Meanwhile, the role of victims in the reconciliation process is to accept and apologize, forget the past, and rebuild distant relationships due to the conflict.

It is not an easy matter for conflict offenders to voluntarily admit a mistake. This difficulty is mainly caused by the fact that in the process of admission, the position of the offender is lower than the victim of the conflict. This admission of a mistake is not any easier for offenders of the 1965 tragedy to make as a result of self-blaming as an accumulation of guilt (Alif, 2004:17). The guilt within the self of Karman is a psychological accumulation as a consequence of regret for mistakes that have been made. This feeling of guilt then becomes a feeling of inferiority and fear that is very strong. This feeling is a result of the negative stigma of society toward the offenders of the 1965 tragedy. This feeling of inferiority becomes further embedded in the minds of the 1965 tragedy offenders because they are systematically cast aside from social life.

Though this is difficult, the admission of mistakes must be done, because, without admission of the truth, actors of the conflict will not be able to determine the moral position of each other. When the position of actors in a conflict has not been determined, matters related to the rights and responsibilities of each party become vague. The admission of Karman as an offender explains the position and responsibilities of the actors of the 1965 tragedy. Karman is a "representative" of left parties (members of the Communist Party and its sectional organizations) who are considered responsible for the occurrence of the 1965 tragedy.

After the process of mistake admission, the truth of the conflict will be revealed. The most fundamental truth is who are offenders and who are victims. In the novel Kubah, the character of Karman is an offender of the 1965 tragedy. Meanwhile, the character of H. Bakir represents the victims of the 1965 tragedy. H. Bakir is a figure realized for the victims of the 1965 tragedy in the imagination of Ahmad Tohari. The victim of a conflict actually possesses the right to ask for retribution or accountability to the offender. This retribution is a logical compensation that must be accepted by the offender as the one who ignited the conflict. A different treatment was given by Ahmad Tohari in the novel Kubah. The conflict victim in the novel did not ask for retribution for the conflict, but instead apologizes, forgets the mistake, and reaccepts the conflict offender in societal life.

The act of the conflict victim in accepting the offender without any retribution is the primary value stressed by Ahmad Tohari. This acceptance process is preceded by a process of forgiving the violation of norms that become the cause of the conflict. There are a variety of concepts of forgiveness in social reconciliation. The concept of forgiveness realized by the victim of the 1965 tragedy in the novel Kubah is the concept of true forgiveness, which is forgiving without apology. This concept of true forgiveness occurs when the forgiver rejects the principle of retribution in relationships among people. H. Bakir as the conflict declined to ask for retribution from Karman as the conflict offender. Even H. Bakir forgave Karman before Karman apologized. This figure of H. Bakir is the ideal picture of conflict victims that have an idea of conflict reconciliation. Through this character, Ahmad Tohari demonstrated the pride and nobleness of the victim of the conflict who prioritized humanity than retribution from the offender. To forgive a mistake is a noble act, and this is more so when the mistake becomes the cause of a national-scale conflict. Though it is noble, the act of forgiving is not one that is easy to perform. Yet forgiving offenders becomes the basis for the last stage of reconciliation, which is healing.

The process of forgiveness that occurs in Kubah directly because of the ideology of santri (Islamic student) understood by Ahmad Tohari. This ideology appears ideally on the figure of Haji Bakir. The portrayal of Haji Bakir as a "form of religion" in Pegaten reinforces it. In the case of ukhuwah there are three behavior conceptual known in the traditional santri circle. The three attitudes are (a) attitude of tawasuth (being middle and wise), (b) tawazun (balanced in carrying out the needs), (c) tasamukh (tolerance of dissent).

The process of forgiveness that occurs in Kubah will not be released from the three concepts of human relationships held by the traditional santri above. Haji Bakir was able to accept and forgive Karman, a former pupil and a person who had self-deceived, must be related to the attitude of tawasuth or be a wise in judging a thing. Forgiveness in Kubah is also due to a high sense of tolerance for differences that occur (tasamukh). Based on these three attitudes, Abdurrahman Wachid on March 14, 2000, tried to reconcile the santri with members of the Communist Party's sympathizers who were victims of the Orde Baru cleansing. Even Abdurrahman Wakhid personally apologized to members of the Communist Party's sympathizers (Mun'im, 2014: 198).

The process of healing after a conflict is a crucial point in the stages of reconciliation. Hamber (in Alif, 2015:297) stated that the process of healing is not only merely a matter of aiding the recovery of psychological health but also to integrally build and repair social and communal contexts. This stage of healing will be realized if the truth regarding offenders-victims has been revealed and there occurs agreement between the two parties that lead to the process of forgiveness. Ahmad Tohari in Kubah brought up this process of healing by involving the two parties involved

\section{2 | ISLLAC : Journal of Intensive Studies on Language, Literature, Art, and Culture}


in the conflict. Personally, the offenders of the 1965 tragedy conducted a positive effort by following all applicable social norms in society. This positive effort certainly creates empathy and sympathy among members of society. This effort to foster sympathy becomes an important matter because society is a local resource that must be led and guided to reaccept the offenders from 1965.

Ahmad Tohari symbolizes the process of building the "Kubah" (dome) of the mosque of Haji Bakir by Karman, as an effort at a reconstructive integration program. The process of building the mosque dome is the symbol of an effort to repair the theological foundation of the 1965 tragedy offenders who were "led astray" by communists. The dome is the peak of a mosque, where symbols are usually placed to represent a vertical relationship with God (lafadz (calligraphy) of Allah, or moon and stars). By building the "dome" at the peak position and in connection with theological symbols, Ahmad Tohari invites Karman and other offenders to return to the right path. This effort of a theological return is strengthened by the citing of the Qur' an chapter of Al-Fajr (Daybreak) at the end of Kubah. In addition to having the meaning of "ideological" repair, the process of dome repair in the novel can also be understood as the active participation of offenders in the effort of assimilating to societal life. This process of building the dome is a symbol of a two-way healing process; one way is the active effort of offenders in partaking in societal processes, and the other way is the presence of sympathy, empathy, and tolerance of victims and the general public to accept the offenders of the 1965 tragedy as "long-lost relatives".

Hai jiwa yang tentram, yang telah sampai kepada kebenaran hakiki. Kembalilah engkau kepada Tuhanmu. Maka masuklah engkau ke dalam berisan hamba-hamba-Ku. Dan masuklah engkau ke dalam kedamaian abadi, di surga-Ku.

[To the righteous it will be said], "O reassured soul, return to your Lord, well-pleased and pleasing [to Him], and enter among My [righteous] servants, and enter My Paradise."

The mentioning of verses from Al-Fajr above is an explicit invitation for "people who have gone astray" to return to righteousness. Ahmad Tohari uses the final four verses of the chapter of Al-Fajr (89:27-30) a depiction of the return of the 1965 tragedy offenders. This process of "return" can be understood as a theological invitation to return to the path of God by believing Him, or could also be an invitation for offenders of the 1965 tragedy to return to society by being responsible for any possible retribution that may occur. These two meanings of "return" have the same goal, which is "eternal peace".

\section{CONCLUSION}

The novel Kubah by Ahmad Tohari is a novel with the theme of the 1965 tragedy that attempted to provide guidelines on the steps of post-conflict reconciliation. Although overall it carries a historical narration that is not very different from the historical narration of the government, this novel has another selling point, which is to see the 1965 tragedy from the viewpoint of the side which has been considered to be the offender of the event. This viewpoint portrays another side to the 1965 tragedy, along with the events that followed it, such as the process of cleansing people considered as offenders, who have colored the rivers red with their blood. But on the other hand, Ahmad Tohari also reveals truths about offenders and their families in relation to the deteriorated psychological condition due to negative stigma as well as the process of arresting and cleansing of offenders of certain categories.

The success of reconciliation of the 1965 tragedy in the novel Kubah is the result of the roles of the offenders and victims. The active role of the offender in admitting the mistake and asking for forgiveness is the primary act that must be done. This recognition and apology form the foundation of the first stage of reconciliation, which is the revealing of truth or internalization. The second stage is the role of the victim in forgiving and not demanding any retribution whatsoever in relation to the offense that caused the conflict in the 1965 tragedy. In the third stage, both sides (offenders and victims) together repair the relationship which has become distanced by looking at the past as a lesson.

Based on a simple and general reading of literature and the particular reading of the novel Kubah, it can be concluded that literature has the potential of being used as a tool to spread the values of resolution of a conflict. In the social revolution of the 1965 tragedy, the widespread publication of literature-themed after the 1965 tragedy will open up access to both opposing parties to obtain different viewpoints. By reading about different viewpoints, the offenders of the 1965 tragedy will feel the effects of the conflict experienced by the victims as a result of the violation of norms that they incurred. Conversely, by reading works from the viewpoint of the offenders, the victims will be able to understand the event from a different viewpoint. In addition, literature has a role in the construction of an "intermediate narration", which is a narration that does not view the 1965 tragedy from the one side of the offender, but views the event holistically from two different sides.

This reading of the novel Kubah shows that works of literature-themed after the 1965 tragedy and published after the event have the opportunity to instill the values of goodness. In other words, literature has played a role in conflict resolution. This finding, though, raises a follow-up question: "how can the values of conflict resolution contained in works of literature be ingrained in a generation that lacks the culture of reading?" God knows the answer.

\section{REFERENCES}

Adam, A.W.(2009). 1965 Orang-Orang di Balik Tragedi. Yogyakarta: Galang Press

Alif, A. (2015). Pemaafan, Rekonsiliasi dan Restorative Justice. Diskursus Perihal Pelanggaran di Masa Lalu dan Upaya-Upaya Melampauinya.Yogayakarta: Pustaka Pelajar

Crouch, H. (1986). Militer dan Politik di Indonesia (terjemahan. Th. Sumarthana). Jakarta: Sinar Harapan

Gitanyali. (2012). 1965. Jakarta: KPG 
Gitanyali. (2012). Blues Merbabu. Jakarta: KPG

Jones, A. (2006). Genocide a Comprehensive Introduction. New York: Routledge

Kasenda, P. (2015). Sarwo edhie dan Tragedi 1965. Jakarta: Kompas

Kayam, U. (1986). Sri Sumarah dan Bawuk. Jakarta: Pustaka Jaya

Kayam, U. (1992). Para Priyayi. Jakarta: PT Pustaka Utama Grafiti

Kayam, U. (2010). Jalan Menikung. Jakarta: PT Pustaka Utama Grafriti

Khudlori, L.S. (2012). "Pulang". Jakarta: Gramedia Pustaka

Kompas, November 20. (2014). Todung Mulya Lubis. Luka Kemanusiaan yang Belum Sembuh.

MABES ABRI. (1994). Bahaya Laten Komunisme di Indonesia (I-V). Pusat Sejarah dan Tradisi ABRI

Mun' im DZ, H. Abdul. (2013). Benturan NU-PKI 1948-1965. Depok: Langgar Swadaya

Notosusanto, N dan Saleh, I. (1989). Tragedi Nasional Percobaan KUP G/30/S/PKI di Indonesia. Jakarta: PT. Intermasa.

Pamuntjak, L. (2012). Amba. Jakarta: Gramedia Pustaka Utama

SETNEG RI. (1994). Gerakan 30 September Pemberontakan Partai Komunis Indonesia Latar Belakang, Aksi, dan Penumpasanya.

Sulistyo, H. (2000). Palu Arit di Ladang Tebu. Jakarta: KPG

Teeuw, A. (1988). Sastra dan Ilmu Sastra. Jakarta: Pustaka Jaya

Tempo. October. (2012). Pengakuan Jagal 1965

Tohari, A. (1995). Kubah. Jakarta: Gramedia Pustaka Utama

Tohari, A. (2009). Ronggeng Dukuh Paruk. Jakarta: Gramedia Pustaka Utama

Verdoleage, A. (2008). Reconciliation Discourse: the Case of the Truth and reconciliation commission. Amsterdam/Philadelphia: John Benjamins (ebook) Publishing Company

Welleck, R and Warren, A. (1989). Teori Kesusastraan (Melani Budianta, trans.). Jakarta: PT. Gramedia

Zoetmulder, P.J., and S.O. Robson. (2011). Kamus Jawa Kuno Indonesia (Darusuprapta and Sumarti Suprayitna, trans.). Jakarta: PT. Gramedia Pustaka Utama. 